\title{
Survival of hemodialysis patients at a university hospital
}

\section{Authors}

Fernanda Ismaela Rolim Teixeira ${ }^{1}$

Maria Lúcia Holanda Lopes ${ }^{1}$

Giselle Andrade dos Santos Silva $^{1}$

Ricardo Ferreira Santos ${ }^{1}$

${ }^{1}$ Federal University of Maranhão (UFMA).

Submitted on: 06/20/2014. Approved on: 07/07/2014.

Correspondence to: Fernanda Ismaela Rolim Teixeira. Hospital Universitário Presidente Dutra da Universidade Federal do Maranhão.

Av. Luís Rocha, no 2142, Monte Castelo. São Luís, MA, Brasil. CEP: 65035-270.

E-mail: nanda_ismaela@ hotmail. com

DOI: 10.5935/0101-2800.20150010

\section{Abstract}

Introduction: Chronic Kidney Disease (CKD) is associated with high rates of morbidity and mortality, especially in dialyses population. Objective: To determine the overall survival rate; the epidemiological and clinical profiles; the comorbidities and the variables associated with survival of the patients undergoing hemodialysis. Methods: This is a longitudinal and descriptive study with 162 patients undergoing hemodialysis, at the University Hospital. The categorical variables were described by frequency and percentage; numerical variables by mean and standarddeviation. The analysis by Cox Regression model was used to study the influence of several clinical and demographic variables in survival rates. Kaplan Meyer model was used to construct the survival curves of the significant variables. Results: The mean age was 48.09 years, and the monthly family income and level of education were reduced in most of the patients studied. Hypertension was the main comorbidity associated with CKD in this population, followed by Diabetes Mellitus. The variables that negatively influenced the survival rates were advanced age at the beginning of therapy and low hemoglobin and albumin levels. The overall survival was $84.41 \%$ and $63.32 \%$ in one and five years, respectively. Conclusion: The rate of survival was considered low compared others studies and was decreasing over the years, not representing improvements despite technological advances in diagnostic and therapeutic approachs. Advanced age, hypoalbuminemia and anemia are strong predictors of mortality.

Keywords: mortality; renal dialysis; survival rate.

\section{INTRODUCTION}

Chronic kidney disease (CKD) consists of kidney damage and/or slow, progressive and irreversible loss of renal function. ${ }^{1}$ It carries high morbidity and mortality. ${ }^{2,3}$

The number of patients with endstage kidney disease (ESRD) treated with renal replacement therapy (RRT) grows globally at a rate of approximately $7 \%$ per year. This rate exceeds the population growth rate. ${ }^{4}$

The three treatment modalities for patients with ESRD are hemodialysis (HD), peritoneal dialysis or kidney transplantation. HD is the most used in the majority of countries. ${ }^{5}$

Between the years of 2000 and 2006 in Brazil, the number of patients in dialysis grew at a rate of about $9 \%$ a year; and the Public Healthcare System (SUS) funded $89 \%$ of that treatment. ${ }^{4}$ According to the census data collected from dialysis units in Brazil, held in July 2010, the number of patients undergoing dialysis was 92,091; $90.6 \%$ in HD. $^{6}$ Epidemiological surveys estimate that there are over 2 million Brazilians having some degree of renal dysfunction and, of these, about $70 \%$ are unaware of the condition. ${ }^{7}$ 
The risk factors that most influence the mortality of dialysis patients are advanced age and diabetes mellitus as causes of chronic renal failure (CRF), and additional comorbidities to the kidney condition. $^{8}$

Azevedo et al., ${ }^{9}$ published a study from Barbacena, Minas Gerais, in which they report that the main causes of death were cardiovascular disease, infections and neoplasms. The overall survival rate found was $86.2 \%$ and $60 \%$, in one and five years, respectively.

In a meta-analysis, Mailloux \& Henrich, cited by Azevedo et al., ${ }^{9}$ reported that HD patient survival time depends on factors such as gender, age, dialysis adequacy ratio $(\mathrm{Kt} / \mathrm{V})$, hemoglobin $(\mathrm{Hb})$, albumin, calcium $\mathrm{x}$ phosphorus product $(\mathrm{CaxP})$ and parathyroid hormone (PTH), among others.

In the study by Barbosa et al., ${ }^{10}$ held in Sao Paulo, high mortality rates were reported, and mortality by CKD was 10 to 20 times higher than in the general population.

The importance of determining survival for renal patients on HD favors the improvement of care, since it enables the early identification of patients at high risk, which improves their survival and quality of life. Besides contributing to the strategic planning of health actions - as evidence suggests that the increase in spending on HD is due to the increased survival of patients and not specifically to the growing demand for treatment. ${ }^{11}$

In São Luís, Maranhão, we did not find studies depicting data correlated with patient survival, we felt motivated to do this study, which aims to determine the survival rate, characterize the clinical and epidemiological profile and identify the comorbidities and the variables associated with survival of patients on hemodialysis.

\section{Method}

This is a descriptive cohort study. We carried out a retrospective and longitudinal study involving
162 CKD patients undergoing $\mathrm{HD}$ at the Nephrology Department of the Presidente Dutra University Hospital at the Federal University of Maranhão - UFMA.

The inclusion criteria were: having started treatment between January 2007 and December 2011; be chronically enrolled in a regular HD program for at least three months, undergoing three sessions per week for 4 hours.

We collected our data from the computerized registration system of the Hemodialysis Service (NEFRODATA-ACD, version 4.5.4.268); information pertaining to gender, age, race, education, family income, CKD cause, length of stay in treatment, comorbidity, destination, cause of death and the results from the following variables - Kt/V, albumin, calcium $\mathrm{x}$ phosphorus, $\mathrm{Hb}$ and PTH. The quality parameters used were: $\mathrm{Kt} / \mathrm{V}>1.2$; Albumin $>3.5 \mathrm{~g} / \mathrm{dl}$; calcium $\mathrm{x}$ phosphorus $<55 \mathrm{mg}^{2} / \mathrm{DL}^{2} ; \mathrm{Hb} \geq 11 \mathrm{~g} / \mathrm{dl}$ and $\mathrm{PTH}=$ $150-300 \mathrm{pg} / \mathrm{ml}$. The data concerned the period from January 2007 to December 2012.

Categorical variables were described by frequencies and percentages, and the numerical variables by using the mean \pm standard deviation. We used the Cox regression analysis to study the influence of various clinical and demographic variables on patient survival. Those variables with $p$-value $<0.10$ were eligible for the multivariate model, a $p$ value $<0.05$ was considered statistically significant.

We used the Kaplan Meyer method to build the survival curves of the significant variables. Statistical analyzes were performed using the Data Analysis and Statistical Software (STATA), version 12.0 .

This study was preceded by the approval from the Ethics Committee of the Federal University of Maranhão, protocol No. 123.351.

\section{Results}

We assessed the medical records from 162 patients, of whom $72(44.44 \%)$ were females and $90(55.56 \%)$ were males. Their average 
age was 48.09 years, with a standard deviation (SD) of 19.88 .

The sociodemographic and clinical characteristics of the patients studied upon dialysis onset, are presented on Table 1.

Regarding treatment duration, considering follow up losses, it was 31.13 months, with SD \pm 42.22. Losses were computed for 68 patients, of whom $14(8.64 \%)$ were transferred to other units; $14(8.64 \%)$ were transplanted; and 40 $(24.69 \%)$ died. At the end of the study period, $94(58.02 \%)$ patients were receiving regular HD.

As to monthly family income and educational level, of the 162 patients, $83(51.23 \%)$ received up to two minimum wages and $140(86.42 \%)$ had up to 8 years of study.

Regarding comorbidities, hypertension and diabetes mellitus were the main causes of comorbidity that prevailed in patients starting dialysis in this study, and $60(37.04 \%)$ patients had more than one associated disease.

Considering the underlying disease, we found that diabetic nephropathy was the prevalent underlying disease $(33.33 \%)$, followed by chronic glomerulonephritis $(22.22 \%)$ and hypertensive nephropathy $(17.28 \%)$.

Table 2 shows data on the survival of patients by year. Importantly, three patients died before reaching one year of study and the survival rate decreased over the years on hemodialysis.

Table 3 depicts the Cox regression univariate analysis results, analyzing the impact of clinical and demographical variables on patient survival. The variables that showed statistically significant influence on survival were: age when starting HD, serum albumin and $\mathrm{Hb}$. Variables such as gender, skin color, educational level, income, diabetes mellitus, cardiovascular disease, $\mathrm{Kt} / \mathrm{V}$, calciumphosphorus product and PTH did not affect patient survival.

In the multivariate analysis (Table 4), the factors associated with patient survival were the same that were significant in the Cox univariate regression analysis. There was a significantly increased hazard ratio (HR) for each additional

\begin{tabular}{|c|c|c|c|}
\hline TABLE 1 & \multicolumn{3}{|c|}{$\begin{array}{l}\text { SOCIODEMOGRAPHIC AND CLINICAL } \\
\text { CHARACTERISTICS OF PATIENTS IN } \\
\text { HEMODIALYSIS CARE IN A UNIVERSITY HOSPITAL } \\
\text { AT TREATMENT ONSET. SÃO LUÍS - MA, } 2012\end{array}$} \\
\hline \multicolumn{2}{|c|}{ Characteristics } & $\mathrm{n}$ & $\%$ \\
\hline \multicolumn{2}{|c|}{$\begin{array}{l}\text { Age in years (mean } \pm \\
\text { SD) }\end{array}$} & & $48.09 \pm 19.88$ \\
\hline \multicolumn{2}{|c|}{$\begin{array}{l}\text { Treatment time - } \\
\text { months (mean } \pm \text { SD) }\end{array}$} & & $31.13 \pm 42.22$ \\
\hline \multicolumn{4}{|l|}{ Gender } \\
\hline \multicolumn{2}{|l|}{ Female } & 72 & 44.44 \\
\hline \multicolumn{2}{|l|}{ Male } & 90 & 55.56 \\
\hline \multicolumn{4}{|c|}{ Skin color } \\
\hline \multicolumn{2}{|c|}{ Not white } & 155 & 95.68 \\
\hline \multicolumn{2}{|l|}{ White } & 7 & 4.32 \\
\hline \multicolumn{4}{|c|}{ Family income } \\
\hline \multicolumn{2}{|c|}{$\begin{array}{l}\text { Up to } 2 \text { minimum } \\
\text { wages }\end{array}$} & 83 & 51.23 \\
\hline \multicolumn{2}{|c|}{2 to 4 Minimum wages } & 9 & 5.56 \\
\hline \multicolumn{2}{|c|}{ > 4 Minimum wages } & 70 & 43.21 \\
\hline \multicolumn{4}{|c|}{ Schooling } \\
\hline \multicolumn{2}{|c|}{$\leq 8$ years } & 140 & 86.42 \\
\hline \multicolumn{2}{|c|}{$>8$ years } & 22 & 13.58 \\
\hline \multicolumn{4}{|c|}{ Comorbidities } \\
\hline \multicolumn{2}{|c|}{ Arterial hypertension } & 67 & 41.36 \\
\hline \multicolumn{2}{|c|}{$\begin{array}{l}\text { Arterial hypertension } \\
\text { and Diabetes Mellitus }\end{array}$} & 42 & 25.93 \\
\hline \multicolumn{2}{|c|}{$\begin{array}{l}\text { Arterial hypertension } \\
\text { and Diabetes Mellitus } \\
\text { and Cardiovascular }\end{array}$} & 12 & 7.41 \\
\hline \multicolumn{2}{|l|}{ Others } & 22 & 13.58 \\
\hline \multicolumn{4}{|c|}{ Underlying disease } \\
\hline \multicolumn{2}{|c|}{$\begin{array}{l}\text { Hypertensive } \\
\text { nephropathy }\end{array}$} & 28 & 17.28 \\
\hline \multicolumn{2}{|c|}{$\begin{array}{l}\text { Chronic } \\
\text { glomerulonephritis }\end{array}$} & 36 & 22.22 \\
\hline \multicolumn{2}{|c|}{ Diabetic nephropathy } & 54 & 33.33 \\
\hline \multicolumn{2}{|l|}{ Others } & 44 & 27.17 \\
\hline \multicolumn{4}{|c|}{ Outcome } \\
\hline \multicolumn{2}{|c|}{ Transferred } & 14 & 8.64 \\
\hline \multicolumn{2}{|l|}{ Death } & 40 & 24.69 \\
\hline Transpla & & 14 & 8.64 \\
\hline $\begin{array}{l}\text { Remaine } \\
\text { program }\end{array}$ & the & 94 & 58.02 \\
\hline
\end{tabular}

year in age upon HD onset. Moreover, considering serum albumin and $\mathrm{Hb}$, we found a significantly lower HR for the higher rates; thus being inversely associated with the risk of mortality. In the set of 


\begin{tabular}{|c|c|c|c|c|c|}
\hline TABLe 2 & \multicolumn{5}{|c|}{$\begin{array}{l}\text { SURVIVAL OF HEMODIALYSIS PATIENTS IN A UNIVERSITY HOSPITAL, BETWEEN } 2007 \text { AND 2011. SÃo LuÍS - MA, } \\
2012\end{array}$} \\
\hline \multicolumn{2}{|c|}{ Follow up duration } & Number of patients & Number of deaths & Survival likelihood & Death likelihood \\
\hline \multicolumn{2}{|l|}{1 year } & 157 & 24 & 0.8471 & 0.1529 \\
\hline \multicolumn{2}{|l|}{2 years } & 97 & 4 & 0.8122 & 0.1878 \\
\hline \multicolumn{2}{|l|}{3 years } & 65 & 2 & 0.7872 & 0.2128 \\
\hline \multicolumn{2}{|l|}{4 years } & 42 & 5 & 0.6935 & 0.3065 \\
\hline \multicolumn{2}{|l|}{5 years } & 23 & 2 & 0.6332 & 0.3668 \\
\hline \multicolumn{2}{|l|}{6 years } & 4 & 0 & 0.6332 & 0.3668 \\
\hline
\end{tabular}

\begin{tabular}{|c|c|c|c|c|}
\hline \multirow{2}{*}{\multicolumn{2}{|c|}{$\begin{array}{l}\text { TABLE } 3 \\
\text { VARIABLE }\end{array}$}} & \multicolumn{3}{|c|}{$\begin{array}{l}\text { ES ON THE SURVIVAL OF PATIENTS IN HEMODIALYSIS IN A UNIVERSITY HOSPITAL, } \\
\text { SSION - UNIVARIATE ANALYSIS). SÃO LUÍS - MA, } 2012\end{array}$} \\
\hline & & Hazard Ratio & $\mathrm{Cl} 95 \%$ & $p$ \\
\hline \multicolumn{2}{|c|}{ Gender (Male x Female) } & 1.19 & $0.86-1.64$ & 0.279 \\
\hline \multicolumn{2}{|c|}{ Skin color (White $x$ Not white) } & 1.39 & $0.42-4.55$ & 0.583 \\
\hline \multicolumn{2}{|c|}{ Schooling ( $\leq 8$ years $x>8$ years) } & 1.97 & $0.93-4.15$ & 0.074 \\
\hline \multicolumn{2}{|c|}{ Income ( $\leq 2$ wages $x>2$ wages $)$} & 0.85 & $0.60-1.18$ & 0.344 \\
\hline \multicolumn{2}{|c|}{ Arterial hypertension (Yes x No) } & 0.52 & $0.27-1.00$ & 0.054 \\
\hline \multicolumn{2}{|c|}{ Diabetes mellitus (Yes $\times$ No) } & 1.48 & $0.79-2.77$ & 0.213 \\
\hline \multicolumn{2}{|c|}{ Cardiovascular disease (Yes $\times$ No) } & 1.13 & $0.44-2.90$ & 0.794 \\
\hline \multicolumn{2}{|c|}{ Age (Years) } & 1.02 & $1.01-1.04$ & 0.001 \\
\hline \multicolumn{2}{|c|}{$\mathrm{Kt} / \mathrm{N}$ (ratio) } & 1.10 & $0.92-1.32$ & 0.259 \\
\hline \multicolumn{2}{|c|}{ Serum albumin } & 0.35 & $0.21-0.58$ & $<0.001$ \\
\hline \multicolumn{2}{|c|}{ Calcium x Phosphorus } & 0.99 & $0.97-1.01$ & 0.727 \\
\hline \multicolumn{2}{|c|}{ Dosed hemoglobin } & 0.48 & $0.37-0.62$ & $<0.001$ \\
\hline \multicolumn{2}{|c|}{ Parathyroid hormone } & 0.99 & $0.99-1.00$ & 0.853 \\
\hline
\end{tabular}

variables analyzed, the educational level factor had only marginally significant effect, with a higher survival rate from patients with more than eight years of schooling. The hypertension variable had no statistically significant influence on patient survival.

\section{Discussion}

As for the sociodemographic characteristics, it is noteworthy that the mean age was 48.09 years with $\mathrm{SD}=19.88$. This result represents a significant social data - as seen in other studies, because ESRD affects a population at full working age, causing spending in social areas due to early retirement, outpatient expenses and medications. ${ }^{10}$

Monthly family income and educational level were reduced in most of the patients investigated, $83(51.23 \%)$ received up to two minimum wages and $140(80.42 \%)$ had up to eight years of schooling, which can affect treatment compliance and decrease the likelihood of an early diagnosis of chronic kidney disease and/or its treatment to slow the disease progression. ${ }^{12-14}$

Hypertension was found to be the major comorbidity associated with ESRD, being present in more than half $(77.77 \%)$ of the patients analyzed, followed by diabetes mellitus (37.66\%). Similar results were found in other studies. ${ }^{10,15}$

Diabetic nephropathy $(33.33 \%)$ was the main underlying disease in the study group, followed by chronic glomerulonephritis $(22.22 \%)$ and hypertensive nephropathy $(17.28 \%)$, contrary to results from some studies, ${ }^{6,13,16}$ i.e. the study from Calado et al. ${ }^{17}$ conducted in São Luís, in 2009. However, these results were partially similar to those found in Rio Grande do Sul in 2007, where the diabetic nephropathy was the most common cause $(24 \%)$ of underlying disease in patients under hemodialysis. ${ }^{18}$ 


\begin{tabular}{|c|c|c|c|c|}
\hline TABLE 4 & $\begin{array}{l}\text { INFLUENCE OF NUMER } \\
\text { HOSPITAL, BETWEEN } 2\end{array}$ & $\begin{array}{l}\text { ABLES ON THE SI } \\
2011 \text { (COX REG }\end{array}$ & $\begin{array}{l}\text { ENTS UNDER } \\
\text { TIVARIATE ANA }\end{array}$ & $\begin{array}{l}\text { UNIVERSITY } \\
\text { - MA, } 2012\end{array}$ \\
\hline VARIABL & & Hazard Ratio & $\mathrm{Cl} 95 \%$ & $p$ \\
\hline Age (Yea & & 1.04 & $1.02-1.06$ & $<0.001$ \\
\hline Schoolins & ( 8 years $x>8$ years) & 2.32 & $0.98-5.52$ & 0.055 \\
\hline Hemoglo & & 0.40 & $0.28-0.57$ & $<0.001$ \\
\hline Serum al & $\min$ & 0.47 & $0.24-0.92$ & 0.029 \\
\hline Arterial h & Dertension (Yes x No) & 0.49 & $0.22-1.07$ & 0.074 \\
\hline
\end{tabular}

In this study, the factors that significantly compromised survival of HD patients were older age at treatment onset, $\mathrm{Hb}$ and serum albumin. Other variables, which in previous studies ${ }^{10,19}$ had an association with patient survival, in this study were not associated with mortality, such as gender, skin color, schooling, income, high blood pressure, diabetes mellitus, cardiovascular diseases, $\mathrm{Kt} / \mathrm{V}$, calcium-phosphorus product and parathyroid hormone.

Several studies have suggested that DM is a predictor of mortality, especially due to cardiovascular causes arising from accelerated aterosclerosis. ${ }^{20}$ Similar results have been found in several studies, ${ }^{18,21-23}$ although this study did not prove such association. One of the limitations of our study, as well as in the study of Angelo et al. ${ }^{20}$ is not to be able to include and evaluate all the variables needed to assess survival in diabetic patients, as the type of DM, smoking, BMI, physical exercise, dyslipidemia. Such information was not possible because of missing data in the records.

The overall mortality rate was $24.69 \%$, with an overall survival of $84.71 \%$ and $63.32 \%$ in one and five years, respectively. This rate is similar to the one reported by Azevedo et al. ${ }^{9}$ and Silva et al. ${ }^{18}$, in which they found $86.2 \%$ in a year and $60 \%$ in five years; $91 \%$ in one year and $64 \%$ in five years, respectively. Large studies show $89 \%$ survival rates at one year and $57 \%$ in five years, respectively, in the countries of the European Dialysis and Transplant Association. $^{24}$

According to the census data from dialysis units in Brazil, ${ }^{6}$ held in July 2010, the gross mortality rate (with the dialysis population on July 1 in the denominator) was $17.9 \%$ during the year. This rate was reduced to 14.9 , when the denominator included patients at risk in the year (who were submitted to dialysis during the year). Studies reported by Dialysis Outcomes and Practice Patterns Study (DOPPS $)^{25}$ consistently showed a marked difference in gross mortality between countries, with mortality in the United States being one of the highest. In 2003, DOPPS reported gross mortality rates at one year being $6.6 \%$ in Japan, $15.6 \%$ in Europe and $21.7 \%$ in the United States. These results show that the overall mortality rate in this study $-24.69 \%$, is above the rates of the Brazilian record as well as those from Japan, Europe and the United States in the studies cited above.

This mortality rate has remained high despite technological advances; which may be explained by the greater severity and age of patients starting treatment, offsetting these data.

Age had a statistically significant impact on patient survival, with an increased HR for each year in the age of hemodialysis onset. This effect strengthens the evidence that mortality rates rise with increasing age. The survival rate was higher in patients who started HD with less than 60 years of age and has remained higher over the months when compared to the survival of patients with 61 years or more (Figure 1). Similar data was also found in other studies. ${ }^{8}$

Regarding $\mathrm{Hb}$, Cox regression univariate and multivariate analyses showed that it had a $52 \%$ $60 \%$ protection factor, respectively, at each increased level, reflecting the current knowledge that patients with higher levels of $\mathrm{Hb}$ have lower mortality. ${ }^{9,26,27}$ However, $\mathrm{Hb}$ was not statistically significant when categorized for the Kaplan Meyer method.

Anemia affects almost all patients undergoing $\mathrm{HD}$, worsens quality of life and is associated with a risk of early death. ${ }^{28-30}$ However, the $\mathrm{Hb}$ 
Figure 1. Survival of patients aged 60 or more vs. Patients younger than $60(p=0.0119)$

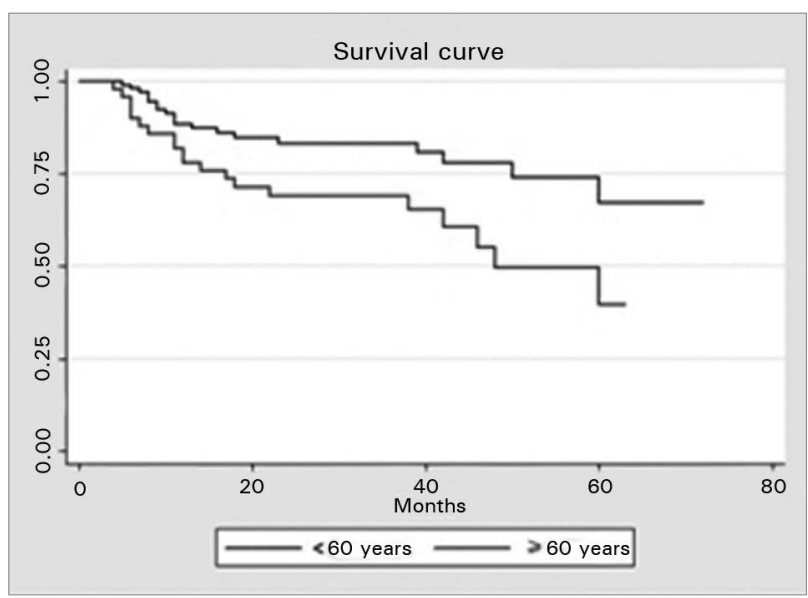

target range is still controversial in Nephrology, since most recent studies show that higher $\mathrm{Hb}$ targets can cause thrombolytic complications, uncontrolled hypertension and mortality. ${ }^{28,31}$ Current recommendations suggest customized treatment for anemia, assigning more freedom to the $\mathrm{Hb}$ value for each patient - taking clinical status and risk factors into account, since some of them will benefit from higher levels of $\mathrm{Hb}$, which will increase their quality of life and compensate for possible risks. ${ }^{31,32}$

Albumin averaged $3,82 \mathrm{~g} / \mathrm{dL} \pm 0.71$ in the patients investigated. Similar results were found in a study in Castelo Branco - Portugal, ${ }^{33}$ in which albumin had mean values above $3.5 \mathrm{~g} / \mathrm{dL}$. It is noteworthy that some authors consider that desirable serum albumin for hemodialysis patients should be $\geq 4.0 \mathrm{~g} / \mathrm{dL}$ and lower values are strongly linked to mortality.

Survival was significantly higher for patients who had albumin values $\geq 3.5 \mathrm{~g} / \mathrm{dL}$ (Figure 2), especially in the first year of hemodialysis treatment, confirming that hypoalbuminemia at hemodialysis onset is a strong predictor of mortality. ${ }^{27,33,34}$

The causes of mortality of patients in this study could not be identified due to impaired information in the records thereof. This is partly due to the fact that many deaths occur in the patient's own home or in other institutions.

This study has its own retrospective-related limitations: 27 cases were excluded due to lack of adequate information.
Figure 2. Patient survival associated with serum albumin $(p=0.0015)$

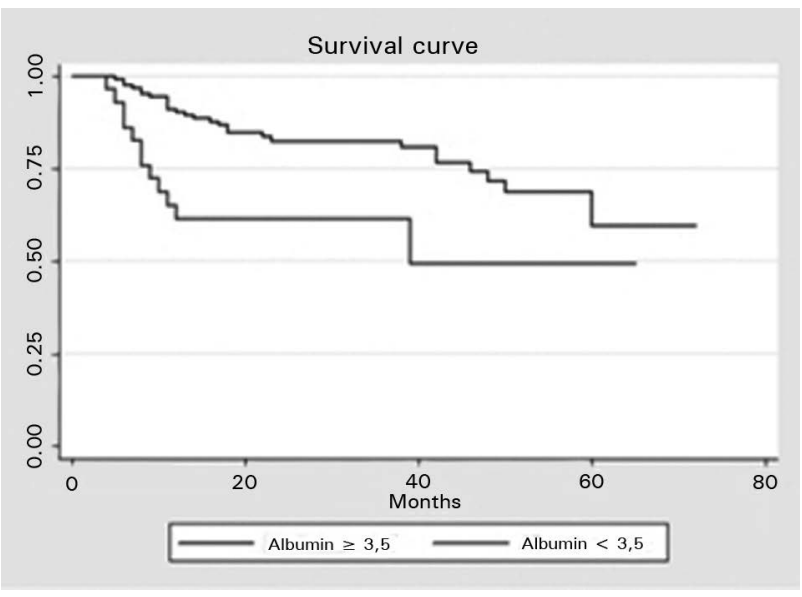

We suggest greater concern for patient records and an active search for information about their deaths, when they do not happen in healthcare centers. This will help us identify the main causes of death of patients in HD and, therefore, seek the best results for their survival.

It is important to stress that several studies show that pre-dialysis nephrology monitoring and the type of vascular access directly influence mortality in the days of hospitalization and even total treatment cost. Thus, these factors represent another limitation to our study, because they were not associated to patient survival.

\section{Conclusions}

This study showed that ESKD in this population affects mostly males, of working age, with low income and low level of education, in addition to confirming that hypertension and diabetes mellitus represent the most prevalent causes of comorbidities in patients in hemodialysis onset. Moreover, advanced age upon treatment onset, $\mathrm{Hb}$ and serum albumin were directly related to survival, with a significantly higher risk for each year in age when starting HD and a significantly lower risk for every increase in $\mathrm{Hb}$ levels and albumin, confirming that advanced age, hypoalbuminemia and anemia are strong predictors of mortality.

Survival rate was considered low and decreased over the years, not showing improvements despite advances in technology, diagnosis and treatment. 
These findings enable the early identification of patients at risk, enabling improvements and adjustments in the care of patients on hemodialysis and, therefore, improvements in the survival and quality of life of such patients.

\section{RefERENCES}

1. Romão Junior JE. Doença renal crônica: definição, epidemiologia e classificação. J Bras Nefrol 2004;26:1-3.

2. Sesso R, Gordan P. Dados disponíveis sobre a doença renal crônica no Brasil. J Bras Nefrol 2007;29:9-12.

3. Spiegel DM. O Paciente em terapia renal substitutiva com diálise. In: Schrier RW. Manual de Nefrologia. São Paulo: Tecmed; 2008. p.237-49.

4. Szuster DAC, Caiaffa WT, Andrade EIG, Acurcio FA, Cherchiglia ML. Sobrevida de pacientes em diálise no SUS no Brasil. Cad Saúde Pública 2012;28:415-24. DOI: http://dx.doi. org/10.1590/S0102-311X2012000300002

5. Terra FS, Costa AMDD. Avaliação da qualidade de vida de pacientes renais crônicos submetidos à hemodiálise. Rev Enferm UERJ 2007;15:430-6.

6. Sesso RC, Lopes AA, Thomé FS, Lugon JR, Santos DR. Relatório do censo brasileiro de diálise de 2010. Rev Bras Nefrol 2011;33:442-7. DOI: http://dx.doi.org/10.1590/S010128002011000400009

7. Sociedade Brasileira de Nefrologia. Perfil da doença renal crônica: o desafio brasileiro [periódico na Internet]. 2007 [Acesso15 Abr 2012]; Disponível em: http://www.prefeitura. sp.gov.br/cidade/secretarias/upload/saude/arquivos/programas/ Doenca_Renal_Cronica.pdf

8. Matos ACC, Sardenberg C, Carvalho COM, Rangel $\mathrm{EB}$, Andreoli CC, Oliveira M, et al. Índice de doenças coexistentes e idade avançada como preditores de sobrevida em pacientes em diálise. Einstein (São Paulo) 2007;5:239-45.

9. Azevedo DF, Correa MC, Botre L, Mariano RM, Assis RR, Grossi L, et al. Sobrevida e causas de mortalidade em pacientes hemodialíticos. Rev Med Minas Gerais 2009;19:117-22.

10. Barbosa DA, Gunji CK, Bittencourt ARC, Belasco AGS, Diccini S, Vattimo $F$ et al. Co-morbidade e mortalidade de pacientes em início de diálise. Acta Paul Enferm 2006;19:304-9. DOI: http://dx.doi.org/10.1590/S010321002006000300008

11. Chaves LDP, Anselmi ML, Barbeira CBS, Hayashida M. Estudo da sobrevida de pacientes submetidos à hemodiálise e estimativa de gastos no município de Ribeirão Preto-SP. Rev Esc Enferm USP 2002;36:193-9. DOI: http://dx.doi.org/10.1590/S008062342002000200013

12. Roberto ES, Santos ED, Ferreira LB, Silva Filho ER. Conhecimento de pacientes com insuficiência renal crônica sobre o tratamento dialítico. Univers Ciênc Saúde 2008;6:131-9.

13. Cherchiglia ML, Machado EL, Szuster DAC, Andrade ELG, Acúrcio FA, Caiaffa WT, et al. Perfil epidemiológico dos pacientes em terapia renal substitutiva no Brasil, 2000-2004. Rev Saúde Pública 2010;44:639-49. DOI: http://dx.doi. org/10.1590/S0034-89102010000400007

14. Santos LTM, Mansur HN, Paiva TFPS, Colugnati FAB, Bastos MG. Letramento em saúde: importância da avaliação em nefrologia. J Bras Nefrol 2012;34:293-302. DOI: http://dx.doi. org/10.5935/0101-2800.20120014

15. Pfuetzenreiter F, Hammes JA, Braatz V, Gonçalves ARR. Morbidade e mortalidade em hemodiálise? Importância do seguimento pré-dialítico e da fonte de financiamento. J Bras Nefrol 2007;29:19-24.
16. Andrade LGM, Gabriel DP, Martin LC, Cruz AP, Balbi AL, Caramori JT, et al. Sobrevida em hemodiálise no hospital das clínicas da faculdade de medicina de Botucatu Unesp: comparação entre a primeira e a segunda metades da década de 90. J Bras Nefrol 2005;27:1-7.

17. Calado IL, Silva AAM, França AKTC, Santos AM, Salgado Filho N. Diagnóstico nutricional de pacientes em hemodiálise na cidade de São Luís (MA). Rev Nutr 2009;22:687-96. DOI: http://dx.doi.org/10.1590/S141552732009000500009

18. Silva LAM, Mezzomo NF, Pensard HM, Arantes LC, Rempel W, Argenta LC, et al. Sobrevida em hemodiálise crônica: estudo de uma coorte de 1.009 pacientes em 25 anos. J Bras Nefrol 2009;31:190-7. DOI: http://dx.doi. org/10.1590/S0101-28002009000300004

19. Argyropoulos C, Chang CC, Plantinga L, Fink N, Powe N, Unruh M. Considerations in the statistical analysis of hemodialysis patient survival. J Am Soc Nephrol 2009;20:203443. DOI: http://dx.doi.org/10.1681/ASN.2008050551

20. Angelo BZ, Tessarollo C, Carvalho VDB, Lemos TC, Koch MC, Maraschin JF. Fatores preditores de mortalidade em pacientes diabéticos em terapia de substituição renal em Tubarão-SC. Arq Catar Med 2010;39:23-8.

21.Zaslavsky LM, Pinotti AF, Gross JL. Diastolic dysfunction and mortality in diabetic patients on hemodialysis: a 4.25year controlled prospective study. J Diabetes Complications 2005;19:194-200. DOI: http://dx.doi.org/10.1016/j.jdiacomp.2004.12.001

22. Hocher B, Ziebig R, Altermann C, Krause R, Asmus G, Richter $\mathrm{CM}$, et al. Different impact of biomarkers as mortality predictors among diabetic and nondiabetic patients undergoing hemodialysis. J Am Soc Nephrol 2003;14:2329-37. DOI: http:// dx.doi.org/10.1097/01.ASN.0000081662.64171.9B

23. Siqueria TMA, Ferreira PAM, Monteiro Júnior FC, Salgado Filho N, Ferreira ASP, Santos Neto E, et al. Parâmetros ecocardiográficos como preditores de eventos cardiovasculares em pacientes em hemodiálise. Arq Bras Cardiol 2012;99:714-23. DOI: http://dx.doi.org/10.1590/S0066-782X2012005000065

24.ERA-EDTA Registry: ERA-EDTA Registry 2008 Annual Report. Academic Medical Center, Department of Medical Informatics, Amsterdam, The Netherlands, [periódico na Internet]. 2010 [Acesso 5 Mai 2013]. Disponível em: http://www.era-edta-reg.org/files/annualreports/pdf/ AnnRep2008.pdf

25. Goodkin DA, Bragg-Gresham JL, Koenig KG, Wolfe RA, Akiba T, Andreucci VE, et al. Association of comorbid conditions and mortality in hemodialysis patients in Europe, Japan, and the United States: the Dialysis Outcomes and Practice Patterns Study (DOPPS). J Am Soc Nephrol 2003;14:3270-7. DOI: http://dx.doi.org/10.1097/01. ASN.0000100127.54107.57

26. Morsch C, Gonçalves LF, Barros E. Índice de gravidade da doença renal, indicadores assistenciais e mortalidade em pacientes em hemodiálise. Rev Assoc Med Bras 2005;51:296-300. DOI: http://dx.doi.org/10.1590/S010442302005000500023

27. National Kidney Foundation. K/DOQI clinical practice guidelines for chronic kidney disease: evaluation, classification, and stratification. Am J Kidney Dis 2002;39:S1-266.

28. Strippoli GF, Craig JC, Manno C, Schena FP. Hemoglobin targets for the anemia of chronic kidney disease: a metaanalysis of randomized, controlled trials. J Am Soc Nephrol 2004;15:3154-65. DOI: http://dx.doi.org/10.1097/01. ASN.0000145436.09176.A7

29. Almeida FAA, Machado FC, Moura Júnior JA, Guimarães AC. Mortalidade global e cardiovascular e fatores de risco de pacientes em hemodiálise. Arq Bras Cardiol 2010;94:201-6. DOI: http://dx.doi.org/10.1590/S0066$782 \times 2010005000003$ 
30. Ammirati AL, Watanabe R, Aoqui C, Draibe SA, Carvalho $\mathrm{AB}$, Abensur $\mathrm{H}$, et al. Variações nos níveis de hemoglobina de pacientes em hemodiálise tratados com eritropoietina: uma experiência brasileira. Rev Assoc Med Bras 2010;56:209-13. DOI: http://dx.doi.org/10.1590/S0104-42302010000200021

31. KDIGO. Clinical Clinical Practice Guideline for Anemia in Chronic Kidney Disease. Kidney Int Suppl 2012;2.

32. FDA Food and Drug Administration handout, 24 June 2012. [Acesso 1 Jun 2014]. Disponível em: http://www.fda.gov/ NewsEvents/Newsroom/PressAnnouncements/ucm260670.htm
33. Oliveira JP. Avaliação nutricional de doentes renais em hemodiálise: trabalho de investigação [monografia na Internet]. Porto: Universidade do Porto; 2008 [Acesso 24 Dez 2014]. Disponível em: http://repositorio-aberto.up.pt/ handle/10216/54461

34. Santos NSJ, Draibe AS, Kamimura MA, Cuppari L. Albumina sérica como marcador nutricional de pacientes em hemodiálise. Rev Nutr 2004;17:339-49. DOI: http://dx.doi.org/10.1590/ S1415-52732004000300007 